\title{
Mons Eugene Bourgeau - 1813-1887
}

\author{
By DR. R. C. RUSSELL, Saskatoon
}

Have you ever wondered who made the first botanical collections in the geographical area, now known as the Prairie Provinces? How thrilling it must have been to sample the flora of a new region for the first time and to discover, occasionally, a species entirely new to science!

There are a number of botanists and amateur collectors whose names are associated with our prairie flora, and we should know more about them and their botanical activities in this region. Let us take Mons Eugene Bourgeau as an example. You may have seen the binomial Rosa bourgeauiana Crep. Various other scientific plant names indicate that this man originally collected them.

Bourgeau was a French botanist who was attached to the exploration party, led by Captain John Palliser, which came out to this country from England in 1857, and spent several summers exploring the plains and parklands of this region while it was still governed by the Hudson's Bay Company. As the expedition worked its way westward, Bourgeau collected plant specimens all the way from Fort William to the Rocky Mountains. These were carefully pressed and dried, often under great difficulties, and were sent back to England, to be studied and classified by the great English botanist, Sir William Hooker.

First we will indicate the districts visited by Mons Bourgeau in company with the expedition led by Captain Pallister. The party reached Fort Garry via Fort William and Lake of the Woods, in July 1857. After due preparation they set out from Fort Garry to explore the southern parts of Rupert's Land. The party was composed of 17 men, 29 horses, 6 Red River carts and 2 waggons. Their route took them south to the boundary line at Pembina, west to the Turtle Mountain, north-west to Fort Ellice, west along the Qu'Appelle Valley to the Elbow of the South Saskatchewan River, which was as far westward as his half-breed helpers would venture in this latitude for fear of the Blackfeet Indians and their allies. The party therefore merely crossed the river here and turned north to Fort Carlton, which they reached on October 8th.

Captain Palliser returned to New York to spend the winter, but the scientific members of his party remained in Rupert's Land, with Carlton as their headquarters, and collected scientific data throughout the winter. In the spring of 1858 , Mons Bourgeau made an extensive collection of the early flowering plants of the Carlton district before the expedition proceeded on its way, June 15, 1858. Among these ne mentions Pulsatilla nuttaliana (ludoviciana), Viola nuttaliana and Amelanchier oralis (alnifolia).

During the summer of 1858 Mons Bourgeau collected plants along the route followed by the expedition. This led south to the Elbow of the North Saskatchewan River, then in a westerly direction across the prairies, via the Eagle Hills, Battle River and Buffalo Lake, to the Rocky Mountains. Here the expedition split up into several smaller parties for limited exploration trips into the mountains in search of suitable passes leading to the west side of the Rockies. Mons Bourgeau was given the services of three men and seven horses with which to carry on a botanical foray for alpine plants, in the month of August. This was in the neighborhood of Banff. Mount Bourgeau commemorates his visit to this region.

The following winter was spent at the Hudson's Bay post of Edmonton, and in the spring of 1859 the expedition under Captain Palliser proceeded with their exploration of the southern prairies and the mountains to the westward. However, Bourgeau was unable to remain with Palliser's party, as he previously had arranged to return to Europe to undertake other botanical work. Therefore he descended the Saskatchewan River with the brigade of York boats taking out the season's fur catch. Turning south on Lake Winnipeg he passed 
through Fort Garry, ascended the Red River and journeyed to the East Coast via St. Paul and Chicago. He seized every opportunity to collect plants between Edmonton and St. Paul on his outward journey.

As a result of his botanical labors in 1857, 58 and 59, Mons Bourgeau sent a total of 819 species of plants to Sir William Hooker. Most of these species were represented by at least twelve specimens. In addition be collected many specimens of seeds, birds' eggs, molluscs and insects. Unfortunately space dces not permit us to mention any details of his extensive collection of plants. However such names as Arabis bourgovii Rybd., Homalobus bourgovii (Gray) Rybd., Lepidum bourgeauanum Thellung and Artemisia bourgeauana Rybd., bear witness to the importance of his contributions to the early studies of our flora. Oxytropis glabrata (Hook) A. Nels. may well be one of the new species sent to Sir William Hooker among the collection of plants gathered by Mons Bourgeau.

We can get a glimpse of the character of the man from the following tribute from his leader, Captain Palliser, in 1858: "M. Bourgeau, who has made a magnificent ccllection of Alpine plants during his tour in the mountains, will return to London, via Pembina and St. Paul's, in order to fulfil his botanical engagements for 1860 . I have to express my thanks to him for his most unceasing exertions, not only in his botanical labours, but for his zeal and care as manager of the provisions and stores of the Expedition, and his anxiety to assist me in every possible way."

\section{TRAGEDY!}

By J. H. Grant, Harlan, Sask.

The month was May; the year was 1910 , and the day was hot and dry. I was busy building a sod shack on my homestead which sat in the centre of a great rolling plain, and was designated by the numbers N.E. $1 / 4 ; 19,17,19$, West of the $3 \mathrm{rd}$.

As the oxen and I moved slowly back and forth with sods or empty boat, I noticed several pairs of

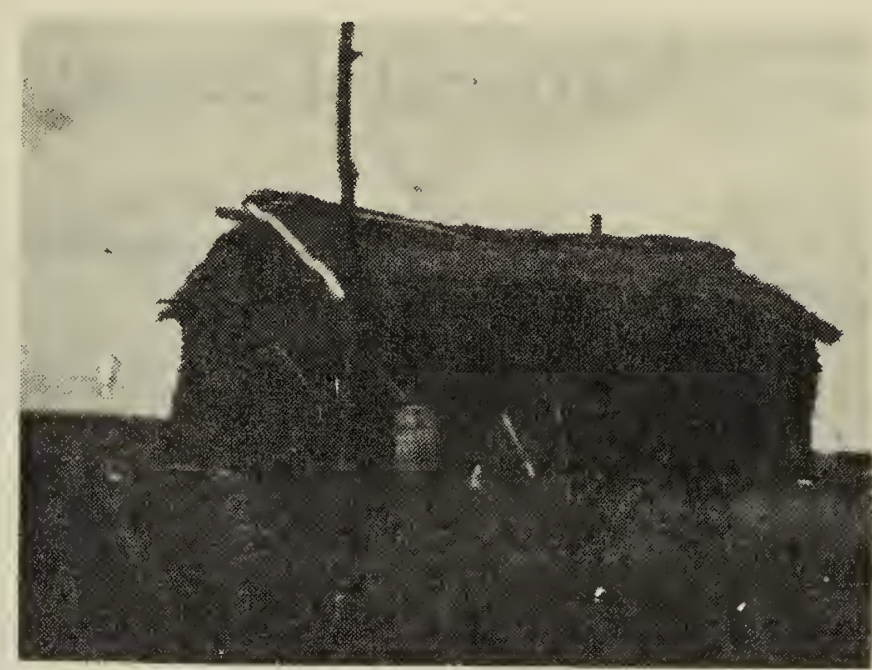

The mansion I was building when I witnessed the lark tragedy.

Horned Larks. They were flying about the newly ploughed furrows, apparently gathering food for their hungry broods. These young were almost fully feathered. They had left the nest and were scattered here and there through the grass.

Presently one pair of birds began to behave in a peculiar manner. They would swoop to the ground, then, without alighting soar up and swoop again; all the time uttering strange cries. They were some distance from my trail but suddenly they were right about my head and shoulders fluttering and chirping - then away again to dive at the ground, as before. They repeated this performance several times.

I stopped the oxen and went to investigate. There on the spot at which the birds were diving, stretched a three-foot Garter Snake with a ycung lark in its mouth. Only the outstretched wings of the bird kept it from being summarily swallowed. The poor little creature was faintly peeping and struggling feebly.

One swish of my ox whip's balewire lash and the reptile's head was severed as neatly as Saladin's sash. The fledgling slipped from the open jaws, gave one tiny chirp and lay still.

The parent birds which had been hovering overhead came down. They seemed no whit afraid of me or the writhing body of the snake. They walked around the little one, eying it closely, then, as though coming to the conclusion that nothing more could be done for it, they rose together and flew off to resume their duties as providers for their remaining young. 